\title{
Semi-Synthesis of Harringtonolide Derivatives and Their Antiproliferative Activity
}

\author{
Xiutao Wu, Lijie Gong, Chen Chen, Ye Tao, Wuxi Zhou, Lingyi Kong * and Jianguang Luo *
}

check for updates

Citation: Wu, X.; Gong, L.; Chen, C.; Tao, Y.; Zhou, W.; Kong, L.; Luo, J. Semi-Synthesis of Harringtonolide Derivatives and Their Antiproliferative Activity. Molecules 2021, 26, 1380. https://doi.org/ $10.3390 /$ molecules 26051380

Academic Editor: Brullo Chiara

Received: 7 February 2021

Accepted: 28 February 2021

Published: 4 March 2021

Publisher's Note: MDPI stays neutral with regard to jurisdictional claims in published maps and institutional affiliations.

Copyright: (c) 2021 by the authors. Licensee MDPI, Basel, Switzerland. This article is an open access article distributed under the terms and conditions of the Creative Commons Attribution (CC BY) license (https:// creativecommons.org/licenses/by/ $4.0 /)$.
State Key Laboratory of Natural Medicines, Jiangsu Key Laboratory of Bioactive Natural Product Research, School of Traditional Chinese Pharmacy, China Pharmaceutical University, 24 Tong Jia Xiang, Nanjing 210009, China; wxtcpuer@163.com (X.W.); jieligong313@163.com (L.G.); chenchen02544@163.com (C.C.); tycpuer@163.com (Y.T.); zhouwuxi1988@163.com (W.Z.)

* Correspondence: cpu_lykong@126.com (L.K.); luojg@cpu.edu.cn (J.L.); Tel.: +86-025-8327-1405 (L.K. \& J.L.)

\begin{abstract}
Harringtonolide (HO), a natural product isolated from Cephalotaxus harringtonia, exhibits potent antiproliferative activity. However, little information has been reported on the systematic structure-activity relationship (SAR) of HO derivatives. Modifications on tropone, lactone, and allyl positions of $\mathrm{HO}(\mathbf{1})$ were carried out to provide 17 derivatives (2-13, 11a-11f). The in vitro antiproliferative activity against four cancer cell lines (HCT-116, A375, A549, and Huh-7) and one normal cell line (L-02) was tested. Amongst these novel derivatives, compound 6 exhibited comparable cell growth inhibitory activity to $\mathrm{HO}$ and displayed better selectivity index $(\mathrm{SI}=56.5)$ between Huh-7 and L-02 cells. The SAR results revealed that the tropone and lactone moieties are essential for the cytotoxic activities, which provided useful suggestions for further structural optimization of $\mathrm{HO}$.
\end{abstract}

Keywords: harringtonolide; troponoids; structure-activity relationship (SAR); antiproliferative activity

\section{Introduction}

Cephalotane-type diterpenoids are widely distributed in the plant of the Cephalotaxus genus [1-5], which is the sole member of the Cephalotaxaceae family. Harringtonolide (also named as hainanolide, $\mathrm{HO}$ ) is the first member of cephalotane-type diterpenoids that was isolated and structurally identified in 1978 from the seeds of Cephalotaxus harringtonia by Buta and coworkers. Structurally, HO, as a typical cephalotane-type diterpenoid, has a tropone ring, a fused tetracarbocyclic skeleton ( $\mathrm{A}-\mathrm{B}-\mathrm{C}-\mathrm{D}$ ring), a bridged lactone (E-ring), and a tetrahydrofuran ring (F-ring) in the molecule. Right after its isolation, it was shown to possess potent plant growth inhibitory [6], antiviral [7], anti-inflammatory [8], and antiproliferative activities $[1,8,9]$. During the past decades, $\mathrm{HO}$ has attracted considerable attention of synthetic chemists because of its unique cage-like troponoid skeleton and remarkable biological effects [10-18]. However, great efforts have been mainly devoted to the total synthesis of HO. Therefore, almost all of these HO derivatives (Figure 1) were extracted and separated from the kingdom of plants, such as hainanolidol with F-ringopening [19], cephanolide A with A-ring-contracted [20], fortalpinoid K without a complete tropone moiety [21], fortalpinoid J [21], cephinoids F-G [8], fortunolide B [22] and 10hydroxyharringtonolide [23] with hydroxy substitutions in $\mathrm{HO}$, and 6-en-harringtonolide with a double bond adjacent to tropone unit [23]. Only 13-Bromoharringtonolide is the semi-synthetic HO derivative reported by Evanno and coworkers [9]. However, to our knowledge, detailed anti-proliferative structure-activity relationship (SAR) for HO (1) is still insufficient up to now. In order to enrich the chemical diversity of $\mathrm{HO}$ and discover pharmacologically interesting compounds, a series of novel $\mathrm{HO}$ derivatives were semisynthesized through substitution at tropone, selective reduction of lactone, and allylic oxidation. Moreover, the antiproliferative activity of these derivatives against the HCT-116 (human colon cancer), A375 (human melanoma cancer), A-549 (human lung adenocarci- 
noma cancer), and Huh-7 (human hepatoma cancer) was evaluated, and their SARs were discussed in the present study.

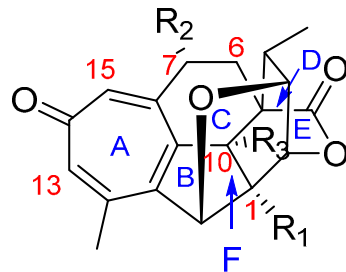

$\begin{array}{lll}\mathrm{R}_{1} & \mathrm{R}_{2} & \mathrm{R}_{3}\end{array}$

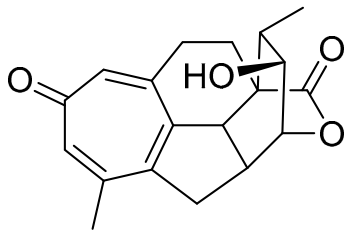

hainanolidol

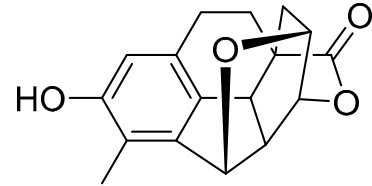

cephanolide A

$\begin{array}{ccccc}\text { cephinoid } \mathrm{F} & \mathrm{H} & \mathrm{OH} & \mathrm{H} & \\ \text { cephinoid } \mathrm{G} & \mathrm{OH} & \mathrm{H} & \mathrm{OH} & \\ \text { fortunolide } \mathrm{B} & \mathrm{OH} & \mathrm{H} & \mathrm{H} & \\ \text { 10-hydroxyharringtonolide } & \mathrm{H} & \mathrm{H} & \mathrm{OH} & \\ \text { fortalpinoid J } & \mathrm{OH} & \mathrm{OH} & \mathrm{H} & \\ \text { 6-en-harringtonolid } & \mathrm{H} & \mathrm{H} & \mathrm{H} & \Delta^{6,7} \\ \text { Harringtonolide }(\mathrm{HO}) & \mathrm{H} & \mathrm{H} & \mathrm{H} & \end{array}$

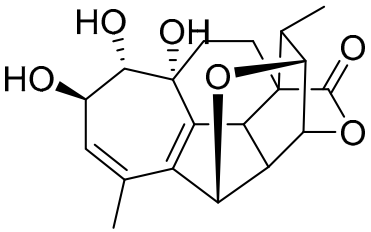

fortalpinoid $\mathrm{K}$

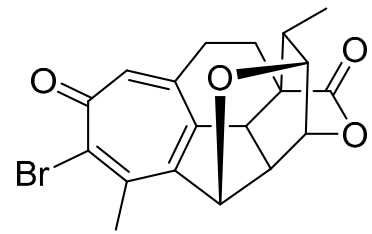

13-bromoharringtonolide

Figure 1. Structures of harringtonolide and its analogues.

\section{Results}

\subsection{Chemical Synthesis}

Two C-15 substituted analogues ( 2 and 3 ) were synthesized to probe and define the importance of the $\mathrm{C}-15$ substituent. Scheme 1 outlines the synthesis of target compounds 2 and 3. The reaction of $\mathbf{1}$ with $\mathrm{NH}_{2}-\mathrm{NH}_{2} \cdot \mathrm{H}_{2} \mathrm{O}$ in $\mathrm{EtOH}$ at room temperature (rt) produced 2 in $96 \%$ yield. Further amidation of 2 with acetyl chloride and $\mathrm{Et}_{3} \mathrm{~N}$ in $\mathrm{CH}_{2} \mathrm{Cl}_{2}$ at $\mathrm{rt}$ provided 3 in $92 \%$ yield.

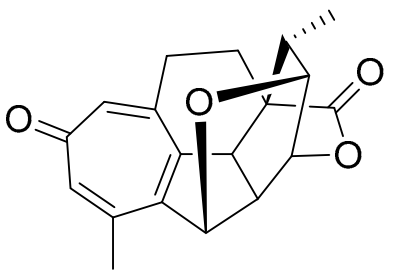

1
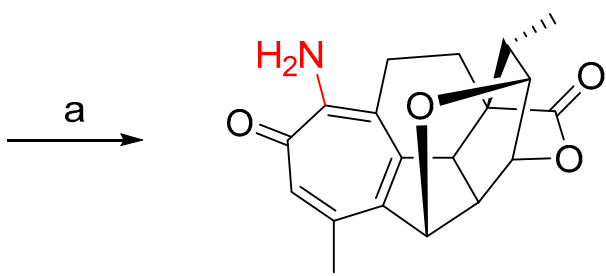

2

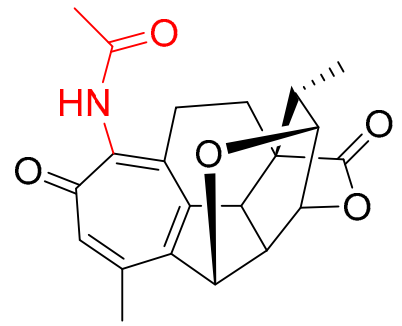

3

Scheme 1. Reagents: (a) $\mathrm{NH}_{2}-\mathrm{NH}_{2} \cdot \mathrm{H}_{2} \mathrm{O}, \mathrm{EtOH}$ and (b) $\mathrm{AcCOCl}, \mathrm{Et}_{3} \mathrm{~N}$.

To explore the role of lactone, compounds with reduced lactone ring (4 and 5 ) were synthesized as shown in Scheme 2. Selective reduction of the lactone with DIBAL-H at $-78{ }^{\circ} \mathrm{C}$ afforded lactol 4 in $24 \%$ yield, which subsequently underwent an esterification reaction with $\mathrm{Ac}_{2} \mathrm{O}$ to give compound 5 in $92 \%$ yield. 


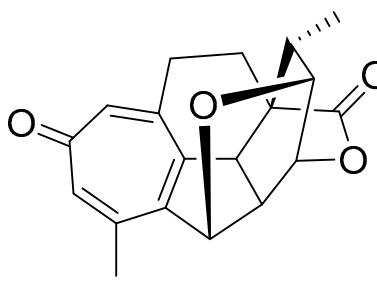

1

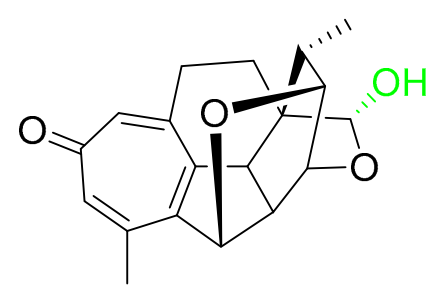

4

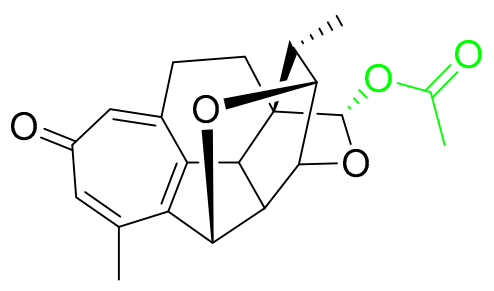

5

Scheme 2. Reagents: (c) DIBAL-H, $\mathrm{CH}_{2} \mathrm{Cl}_{2}$ and (d) $\mathrm{Ac}_{2} \mathrm{O}$, Pyr.

In order to discover $\mathrm{HO}$ derivatives with diverse allyl alcohol replacements, allylic oxidation of $\mathrm{HO}$ with $\mathrm{SeO}_{2}$ was conducted. Interestingly, under the condition of Riley oxidation ( $\left.\mathrm{SeO}_{2} / \mathrm{TBHP}\right)$ at rt, compounds 6 with a double bond between C-6 and C-7 in 16\% yield and 7 with A-ring contracted in 5\% yield were produced as shown in Scheme 3 . The structure of compound $\mathbf{6}$ is consistent with the natural product 6-en-harringtonolide [23] isolated from Cephalotaxus mannii as shown in Figure 1. The formation of compound $\mathbf{6}$ was likely based on the elimination of hydroxyl. A possible mechanism for the formation of 7 is presented in Scheme S1, which is meaningful to explore the conversion of tropone to benzene ring in cephalotane-type diterpenoids.

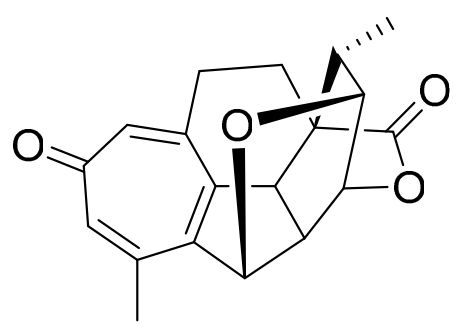

1

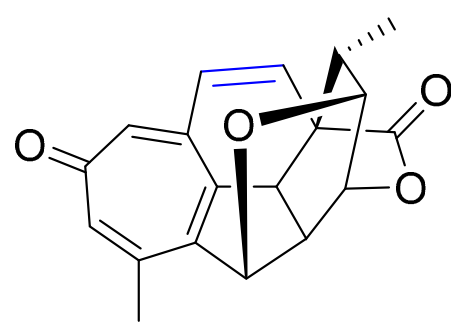

6

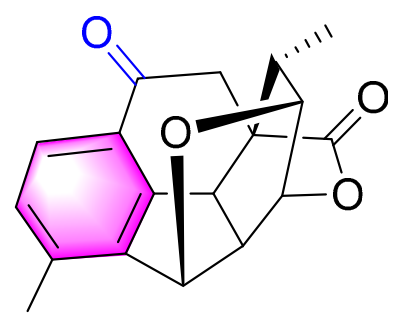

7

Scheme 3. Reagents: (e) $\mathrm{SeO}_{2} / \mathrm{TBHP}$ and $\mathrm{CH}_{2} \mathrm{Cl}_{2}$.

Next, another route was designed to obtain our target compounds. At the beginning, $\mathrm{HO}$ (1) was treated with NBS/AIBN at $65{ }^{\circ} \mathrm{C}$ for $12 \mathrm{~h}$ to obtain compound $7 \alpha$-Br harringtonolide (8) in 54\% yield. Compound 8 was then subjected to hydrolysis with $\mathrm{AgBF}_{4}$ in acetone $/ \mathrm{H}_{2} \mathrm{O}$ at $65{ }^{\circ} \mathrm{C}$ to produce $7 \beta-\mathrm{OH}$ harringtonolide (10) in $47 \%$ yield and $7 \alpha-\mathrm{OH}$ harringtonolide (12) in $21 \%$ yield (Scheme 4 ). The $\beta$-orientation of $7-\mathrm{OH}$ in compound 10 was deduced from the ROESY correlations (Figure S1) of 7-H with 1-H and 10-H. The structure of compound $\mathbf{1 2}$ is identical to the natural product cephinoid F [8] isolated from Cephalotaxus lanceolata as shown in Figure 1.

Furthermore, to explore the effects of hydroxy group and its stereochemistry of $\mathrm{HO}$ on antiproliferative activity, a series of $\mathrm{HO}$ derivatives were designed in which the hydroxy at C-7 was modified as shown in Scheme 4 . The cytotoxicity assay (vide infra) of these two compounds indicated that the stereochemistry at C-7 influences the cytotoxic activities with $\beta$-orientation favored. Thus, compound $\mathbf{1 0}$ was then coupled with acyl moieties to its $7 \beta-\mathrm{OH}$ position to afford a series of new ester derivatives 11a-11f. The 3,5,6trimethylpyrazine-2-carboxylic acid (TMPA), used in the synthesis of 11f, was obtained according to the previous report [24]. Interestingly, treatment of 8 with $\mathrm{MeONa} / \mathrm{MeOH}$ at rt provided 9 with a methoxy substituent at tropone in $72 \%$ yield rather than allyl position, the generation of 9 may be through the rearrangement of allyl carbocation and subsequent replacement by methoxy anion (Scheme S2). The oxidation of hydroxy in compound 12 with Dess-Martin periodinane (DMP) in $\mathrm{CH}_{2} \mathrm{Cl}_{2}$ at rt produced 13 in $78 \%$ yield. 


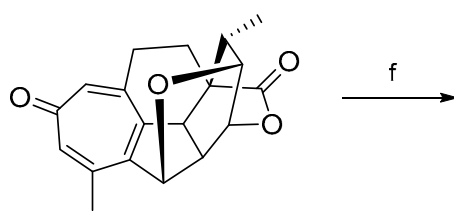

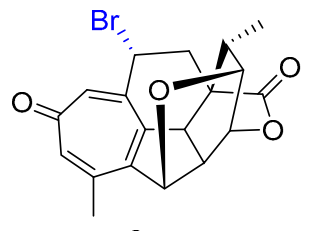

8

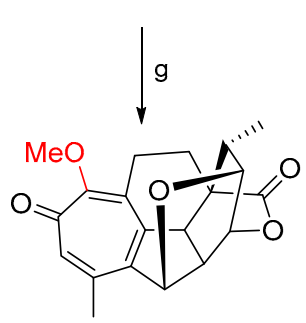

9

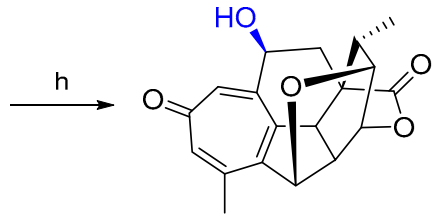

10

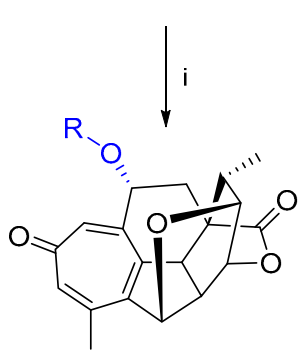

11a-11f

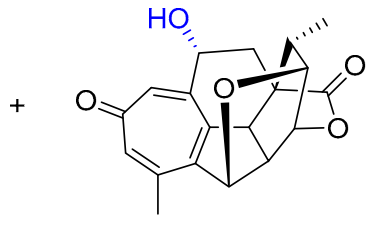

12

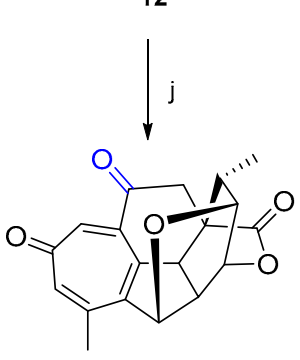

13<smiles>CC(C)=O</smiles>

11d<smiles>CC(C)(C)C(=O)CCC(=O)O</smiles>

11b<smiles>NC(=O)c1ccccn1</smiles>

$11 \mathrm{e}$<smiles>NC(=O)c1ccco1</smiles>

11c<smiles>Cc1nc(C)c(C(=O)O)nc1C</smiles>

$11 \mathrm{f}$

Scheme 4. Reagents: (f) NBS/AIBN, DCE; (g) $\mathrm{MeONa} / \mathrm{MeOH}$; (h) $\mathrm{AgBF}_{4}$, acetone $/ \mathrm{H}_{2} \mathrm{O}$; (i) $\mathrm{RCOOH}$, EDCI/DMAP; and (j) DMP, $\mathrm{CH}_{2} \mathrm{Cl}_{2}$.

\subsection{Cytotoxicity}

All the synthesized derivatives of $\mathrm{HO}$ were tested for their antiproliferative activity against four human cancer cell lines, including the HCT-116, A375, A-549, and Huh-7 cell lines, using the MTT assay. Cisplatin was used as a positive control, while lead compound $\mathrm{HO}(1)$ was also included in the study for comparison. $\mathrm{IC}_{50}$ values $(50 \%$ inhibition concentration of cell viability) of the tested compounds were summarized in Table 1.

Parent compound 1 showed strong potency against HCT-116, A375, A549, and Huh7 cells with $\mathrm{IC}_{50}$ values of $0.61,1.34,1.67$, and $1.25 \mu \mathrm{M}$, respectively. Unfortunately, compounds 2-5, 7, and 9 were inactive against four tested cancer cells at $50 \mu \mathrm{M}$. The results revealed that structural variations in the tropone ring and lactone will dramatically impact the cytotoxic activities. 7-OH, 7-keto, or 7-ester group derivatives 10-13 showed weak cytotoxic activities or were inactive. In particular, compound $\mathbf{6}$ showed comparable cytotoxic activities to $\mathrm{HO}$ against HCT-116 and Huh-7 cells with $\mathrm{IC}_{50}$ values of 0.86 and $1.19 \mu \mathrm{M}$, respectively.

The selectivity index is crucial for drug development, because it could mediate side effects, including tissues toxicity $[25,26]$. Therefore, according to cytotoxic activity results, compounds $\mathbf{6}$ and $\mathbf{1 0}$ with potent cytotoxicity in Huh-7 cells were selected to investigate the selectivity between normal and cancer cells. These two compounds were tested on human normal hepatic L-02 cells with $\mathrm{HO}$ as control. The results are listed in Table 2. Interestingly, compound 6 displayed obvious selectivity between Huh-7 and L-02 cells with SI $=56.5$ compared with the parent compound 1 with $\mathrm{SI}=2.8$. 
Table 1. The in-vitro cytotoxicity of the harringtonolide (HO) analogues.

\begin{tabular}{ccccc}
\hline \multirow{2}{*}{ Compounds } & \multicolumn{4}{c}{ IC $_{\mathbf{5 0}}(\boldsymbol{\mu M})$} \\
\cline { 2 - 5 } & HCT-116 & A375 & A549 & Huh-7 \\
\hline HO (1) & $0.61 \pm 0.03$ & $1.34 \pm 0.23$ & $1.67 \pm 0.23$ & $1.25 \pm 0.08$ \\
$\mathbf{2}$ & $>50$ & $>50$ & $>50$ & $>50$ \\
$\mathbf{3}$ & $>50$ & $>50$ & $>50$ & $>50$ \\
$\mathbf{4}$ & $>50$ & $>50$ & $>50$ & $>50$ \\
$\mathbf{5}$ & $>50$ & $>50$ & $>50$ & $>50$ \\
$\mathbf{6}$ & $0.86 \pm 0.05$ & $4.85 \pm 0.42$ & $5.47 \pm 0.13$ & $1.19 \pm 0.08$ \\
$\mathbf{7}$ & $>50$ & $>50$ & $>50$ & $>50$ \\
$\mathbf{8}$ & $2.19 \pm 0.23$ & $3.40 \pm 0.22$ & $43.40 \pm 1.08$ & $30.75 \pm 0.60$ \\
$\mathbf{9}$ & $>50$ & $>50$ & $>50$ & $>50$ \\
$\mathbf{1 0}$ & $2.29 \pm 0.27$ & $5.79 \pm 1.26$ & $8.25 \pm 0.20$ & $6.34 \pm 0.32$ \\
$\mathbf{1 1 a}$ & $5.95 \pm 0.45$ & $30.13 \pm 1.58$ & $27.49 \pm 0.89$ & $>50$ \\
$\mathbf{1 1 b}$ & $>50$ & $>50$ & $>50$ & $>50$ \\
$\mathbf{1 1}$ & $10.98 \pm 0.34$ & $16.42 \pm 1.92$ & $23.25 \pm 0.67$ & $>50$ \\
$\mathbf{1 1 d}$ & $>50$ & $>50$ & $>50$ & $>50$ \\
$\mathbf{1 1 e}$ & $5.47 \pm 0.27$ & $7.08 \pm 0.42$ & $17.98 \pm 4.18$ & $>50$ \\
$\mathbf{1 1 f}$ & $10.77 \pm 0.42$ & $18.56 \pm 2.23$ & $25.95 \pm 0.68$ & $>50$ \\
$\mathbf{1 2}$ & $31.88 \pm 0.69$ & $40.42 \pm 7.58$ & $34.72 \pm 1.94$ & $>50$ \\
$\mathbf{1 3}$ & $>50$ & $>50$ & $>50$ & $>50$ \\
Cisplatin & $4.48 \pm 0.18$ & $4.04 \pm 0.23$ & $8.53 \pm 0.98$ & $15.04 \pm 0.15$ \\
\hline
\end{tabular}

Table 2. Cytotoxicity of compounds $\mathbf{1}, \mathbf{6}$ and $\mathbf{1 0}$ on L-02 cells.

\begin{tabular}{cccc}
\hline \multirow{2}{*}{ Compound } & \multicolumn{2}{c}{ IC $_{\mathbf{5 0}}(\boldsymbol{\mu M})$} & \multirow{2}{*}{ SI $^{\boldsymbol{a}}$} \\
\cline { 2 - 3 } & Huh-7 & L-02 & \\
\hline $\mathbf{6}$ & $1.19 \pm 0.08$ & $67.2 \pm 0.43$ & 56.5 \\
$\mathbf{1 0}$ & $6.34 \pm 0.32$ & $22.33 \pm 1.11$ & 3.5 \\
HO (1) & $1.25 \pm 0.08$ & $3.46 \pm 0.36$ & 2.8 \\
\hline
\end{tabular}

${ }^{a}$ Selectivity index is defined as $\mathrm{IC}_{50}(\mathrm{~L}-02) / \mathrm{IC}_{50}$ (Huh-7).

\section{Discussion}

Combined with previous reports $[8,21]$, systematic SAR of the $\mathrm{HO}$ analogues as antiproliferative agents (Figure 2) was discussed as follows based on above-described results. (1) From the screening results in Table 1, it was observed that substitution with a bromine atom, an amino or a methoxy group at tropone (2-bromoharringtonolide [9] and compounds 2-3, 9), lack of tropone ring (fortalpinoid K [21]), and A-ring contraction of tropone (cephanolide A [20] and compound 7) in HO led to losing of cytotoxic activities. (2) Reduction of lactone in $\mathrm{HO}$ also led to losing of cytotoxic activities as observed in the compounds 4 and 5 . These results indicated that the tropone and lactone moieties are essential for the cytotoxic activities. (3) The introduction of an $\alpha$-oriented hydroxyl at C-7 or other positions drastically decreased cytotoxic activities in accord with previous reports [8,21-23], whereas the presence of a $7 \beta-\mathrm{OH}$ exerts no obvious effects on the cytotoxic activities against HCT-116 cells as observed in the cases of compounds $10\left(\mathrm{IC}_{50}=2.29 \mu \mathrm{M}\right)$ and $12\left(\mathrm{IC}_{50}=31.88 \mu \mathrm{M}\right)$. However, further esterification at $7 \beta-\mathrm{OH}$ greatly decreased cytotoxic activities against A549 cells in different levels as observed in compounds 11a $\left(\mathrm{IC}_{50}=27.49 \mu \mathrm{M}\right), \mathbf{1 1} \mathbf{c}\left(\mathrm{IC}_{50}=23.25 \mu \mathrm{M}\right), \mathbf{1 1 e}\left(\mathrm{IC}_{50}=17.98 \mu \mathrm{M}\right)$, and 11f $\left(\mathrm{IC}_{50}=25.95 \mu \mathrm{M}\right)$ compared with $\mathrm{HO}\left(\mathrm{IC}_{50}=1.67 \mu \mathrm{M}\right)$ or led to losing of cytotoxic activities as observed in compounds $11 \mathrm{~b}$ and $11 \mathrm{~d}$ ( $\mathrm{IC}_{50}>50 \mu \mathrm{M}$ against tested cells). The compounds 11a, 11c, 11e, and 11f also showed weak cytotoxic activities against three other cancer cell lines. This could be attributed to the steric hindrance that affecting the binding of compounds to their targets [27,28]. (4) The presence of a double bond adjacent to the tropone unit had no obvious effects on the cytotoxic activities against HCT-116 and Huh-7 cells as observed in the cases of compound 6 ( $\mathrm{IC}_{50}=0.86$ and $1.19 \mu \mathrm{M}$, respectively) compared with $\mathrm{HO}$ 
$\left(\mathrm{IC}_{50}=0.61\right.$ and $1.25 \mu \mathrm{M}$, respectively) but obviously increased the selectivity between Huh-7 and L-02 cells, as observed in Table 2. The selectivity index of compound $\mathbf{6}(\mathrm{SI}=56.5$ ) was 20 times higher than $\mathrm{HO}(\mathrm{SI}=2.8)$. (5) Carbonyl adjacent to the tropone motif led to losing of cytotoxic activities, as observed in $\mathbf{1 3}$ ( $\mathrm{IC}_{50}>50 \mu \mathrm{M}$ against tested cells).

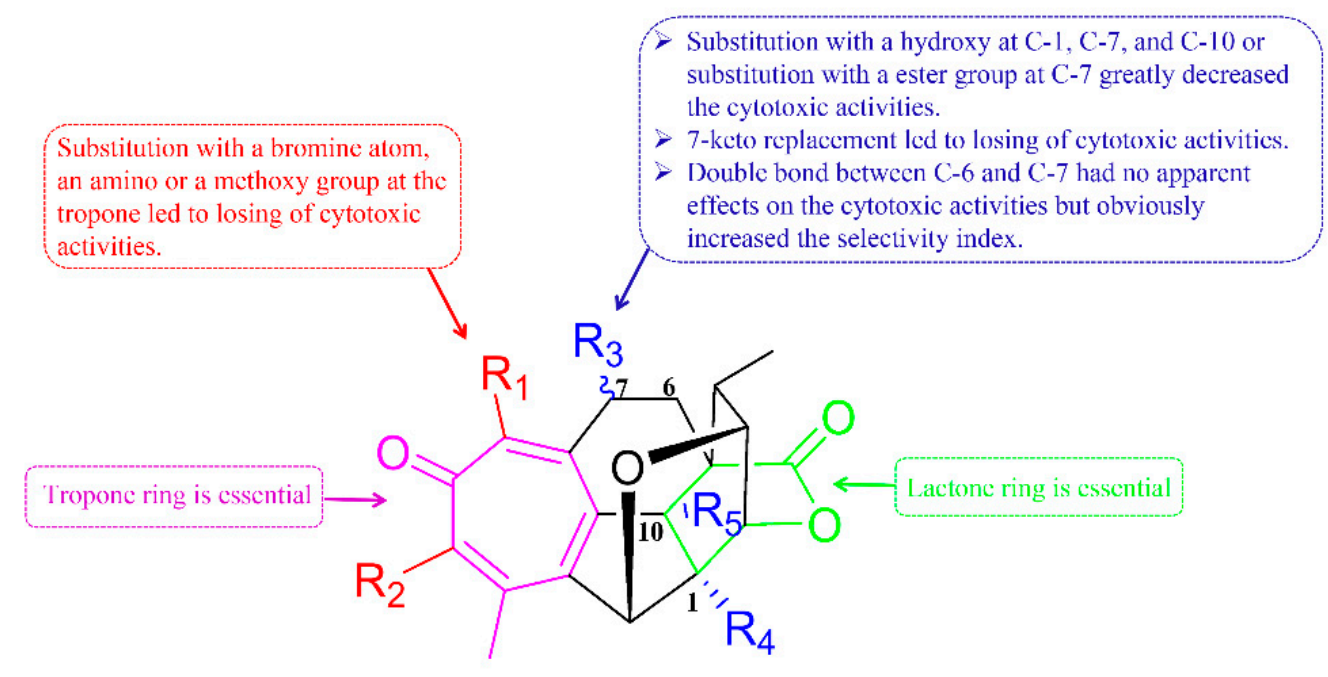

Figure 2. Systematic structure-activity relationship (SAR) of harringtonolide (HO) derivatives.

According to the SAR analysis of HO derivatives, compound 6 exhibited the most potent antiproliferative activity and low toxicity. Our studies indicated that analogue 6 could be further investigated as an antitumor drug candidate. Additionally, there is an urgent need for thorough research to understand the mechanism of action and targets of this kind of analogues.

\section{Materials and Methods}

\subsection{Chemistry}

$\mathrm{HO}$, used as starting material, was isolated from Cephalotaxus fortunei Hook. f. by our group, and its structure was identified by ESI-MS and NMR. All reagents were purchased from Energy Chemical (Shanghai, China) and Aladdin (Shanghai, China) and were used without any further purification. Thin-layer chromatography (TLC) was performed using silica gel plates (GF254, Qingdao Marine Chemical Ltd., Qingdao, China) and visualized under ultraviolet (UV) light $(254 \mathrm{~nm})$. Silica gel column chromatography was performed using 200-300 mesh (Qingdao Marine Chemical Ltd., Qingdao, China).

NMR spectra were recorded on Bruker Avance III-500 and Bruker Avance III-600 spectrometers (Bruker, Karlsruhe, Germany) at ambient temperature using TMS as the internal standard. High-resolution electrospray ionization (HRESI) mass spectra were carried out using an Agilent 6520B Q-TOF mass spectrometer (Agilent Technologies, Santa Clara, CA, USA). All final compounds have purity $>95 \%$ (Figure S2) as determined by an Agilent 1260 instrument equipped with VWD detector (Agilent Technologies, Santa Clara, CA, USA) using a COSMOSIL 5C18-AR-II column $(250 \mathrm{~mm} \times 4.6 \mathrm{~mm}$, i.d., $5 \mu \mathrm{m}$, Nacalai Tesque, Kyoto, Japan).

\subsubsection{General Procedure for the Synthesis of Compounds 2 and 3}

To a solution of $\mathbf{1}(310 \mathrm{mg}, 1 \mathrm{mmol})$ in $\mathrm{EtOH}(10 \mathrm{~mL}), 80 \%$ hydrazine monohydrate $\left(\mathrm{NH}_{2}-\mathrm{NH}_{2} \cdot \mathrm{H}_{2} \mathrm{O} ; 5 \mathrm{~mL}\right)$ was added. The solution was allowed to stir at $\mathrm{rt}$ for $8 \mathrm{~h}$ until all starting material was consumed as determined by TLC. The reaction was quenched by the addition of $\mathrm{H}_{2} \mathrm{O}$, and the mixture was extracted with $\mathrm{CH}_{2} \mathrm{Cl}_{2}$. The combined organic layers were dried over $\mathrm{Na}_{2} \mathrm{SO}_{4}$, and concentrated under reduced pressure. The residue was 
purified by column chromatography using $\mathrm{CH}_{2} \mathrm{Cl}_{2}-\mathrm{MeOH}$ (10:1) to afford 2 as a yellow solid (312 $\mathrm{mg}, 96 \%)$.

(3R,4aR,10aS,11S)-8-amino-5,11-dimethyl-2a,3,4a,9,10,10a1-hexahydro-1H-2,4-dioxa-3,10amethanocyclohepta[bc]cyclopenta[jk]acenaphthylene-1,7(2a1H)-dione (2).

${ }^{1} \mathrm{H}-\mathrm{NMR}\left(600 \mathrm{MHz}, \mathrm{CDCl}_{3}\right): \delta 7.18(\mathrm{~s}, 1 \mathrm{H}), 6.07$ (brs, $\left.2 \mathrm{H}\right), 5.43(\mathrm{~d}, J=4.9 \mathrm{~Hz}, 1 \mathrm{H})$, $5.19(\mathrm{t}, J=5.5 \mathrm{~Hz}, 1 \mathrm{H}), 3.95(\mathrm{~d}, J=5.7 \mathrm{~Hz}, 1 \mathrm{H}), 3.38-3.32(\mathrm{~m}, 2 \mathrm{H}), 2.90(\mathrm{ddd}, J=14.6$, $7.8,1.3 \mathrm{~Hz}, 1 \mathrm{H}), 2.80(\mathrm{ddd}, J=15.5,6.4,1.4 \mathrm{~Hz}, 1 \mathrm{H}), 2.65(\mathrm{ddd}, J=15.4,11.9,7.7 \mathrm{~Hz}, 1 \mathrm{H})$, $2.42(\mathrm{~s}, 3 \mathrm{H}), 1.68(\mathrm{q}, J=7.6 \mathrm{~Hz}, 1 \mathrm{H}), 1.29(\mathrm{ddd}, J=14.6,11.9,6.4 \mathrm{~Hz}, 1 \mathrm{H}), 0.86(\mathrm{~d}, J=7.6 \mathrm{~Hz}$, 3H). ${ }^{13} \mathrm{C}-\mathrm{NMR}\left(151 \mathrm{MHz}, \mathrm{CDCl}_{3}\right): \delta 175.67,174.19,152.80,148.32,144.17,135.71,132.71$, $118.29,85.95,80.21,78.99,50.79,45.47,42.01,40.56,25.35,24.00,22.91,14.81$. HR-MS (ESI) $m / z: 443.1101[\mathrm{M}+\mathrm{Na}]^{+}$(Calcd for $\left.\mathrm{C}_{19} \mathrm{H}_{19} \mathrm{NNaO}_{4}: 443.1101\right)$.

To a solution of $2(8.1 \mathrm{mg}, 0.025 \mathrm{mmol})$ in $1 \mathrm{~mL}$ of anhydrous dichloromethane, triethylamine (TEA; $6.9 \mu \mathrm{L}, 0.05 \mathrm{mmol})$ was added, and then, acetyl chloride $(2.7 \mu \mathrm{L}$, $0.0375 \mathrm{mmol}$ ) was added to the solution at $0{ }^{\circ} \mathrm{C}$. The resulting solution was allowed to warm to rt and stirred for $4 \mathrm{~h}$. Then, the reaction was quenched with water and extracted with dichloromethane. The combined organic phases were washed with brine, dried over $\mathrm{Na}_{2} \mathrm{SO}_{4}$, and concentrated in vacuo. The residue was purified by column chromatography using hexanes-EtOAc (1:2) to afford 3 as a yellow solid ( $8.4 \mathrm{mg}, 92 \%)$.

$N-((3 R, 4 a R, 10 a S, 11 S)-5,11$-dimethyl-1,7-dioxo-2a,2a1,3,4a,7,9,10,10a1-octahydro-1H-2,4dioxa-3,10a-methanocyclohepta[bc]cyclopenta[jk]acenaphthylen-8-yl) acetamide (3).

${ }^{1} \mathrm{H}-\mathrm{NMR}\left(500 \mathrm{MHz}, \mathrm{CDCl}_{3}\right): \delta 8.68(\mathrm{~s}, 1 \mathrm{H}), 7.22(\mathrm{~s}, 1 \mathrm{H}), 5.40(\mathrm{~d}, J=5.5 \mathrm{~Hz}, 1 \mathrm{H})$, $5.20(\mathrm{t}, J=5.7 \mathrm{~Hz}, 1 \mathrm{H}), 3.97(\mathrm{~d}, J=5.6 \mathrm{~Hz}, 1 \mathrm{H}), 3.52(\mathrm{~d}, J=8.9 \mathrm{~Hz}, 1 \mathrm{H}), 3.39(\mathrm{dt}, J=8.9$, $5.7,1 \mathrm{H}), 2.80(\mathrm{dq}, J=12.7,8.0 \mathrm{~Hz}, 2 \mathrm{H}), 2.64-2.57(\mathrm{~m}, 1 \mathrm{H}), 2.43(\mathrm{~s}, 3 \mathrm{H}), 2.26(\mathrm{~s}, 3 \mathrm{H}), 1.70(\mathrm{q}$, $J=7.6 \mathrm{~Hz}, 1 \mathrm{H}), 1.21-1.13(\mathrm{~m}, 1 \mathrm{H}), 0.86(\mathrm{~d}, J=7.5 \mathrm{~Hz}, 3 \mathrm{H}) .{ }^{13} \mathrm{C}-\mathrm{NMR}\left(126 \mathrm{MHz}, \mathrm{CDCl}_{3}\right): \delta$ $179.73,173.72,168.74,147.10,145.28,143.03,141.91,138.19,136.84,86.21,80.24,79.72,50.89$, $45.64,42.26,40.30,30.29,24.58,24.15,22.31,14.87$. HR-MS (ESI) $m / z: 390.1311[\mathrm{M}+\mathrm{Na}]^{+}$ (Calcd for $\mathrm{C}_{21} \mathrm{H}_{21} \mathrm{NNaO}_{5}$ : 390.1312).

\subsubsection{General Procedure for the Synthesis of Compounds 4 and 5}

To a solution of $\mathbf{1}(155 \mathrm{mg}, 0.5 \mathrm{mmol})$ in $\mathrm{CH}_{2} \mathrm{Cl}_{2}(5 \mathrm{~mL})$, diisobutylaluminum hydride (DIBAL-H; $1.0 \mathrm{M}$ solution in hexane, $1.3 \mathrm{~mL}, 1.3 \mathrm{mmol}$ ) was added in 3 portions at $-78^{\circ} \mathrm{C}$ under nitrogen, and the mixture was stirred at $-78{ }^{\circ} \mathrm{C}$ for $3 \mathrm{~h}$. Saturated aqueous sodium potassium tartrate was then added to quench the reaction. The resulting mixture was extracted with $\mathrm{CH}_{2} \mathrm{Cl}_{2}$. The combined organic layers were washed with brine, dried over anhydrous $\mathrm{Na}_{2} \mathrm{SO}_{4}$, filtered, and concentrated under reduced pressure. The residue was purified by column chromatography on silica gel by eluting with $\mathrm{CH}_{2} \mathrm{Cl}_{2}-\mathrm{MeOH}$ (20:1) to furnish the corresponding lactol 4 as a yellow solid (37.5 $\mathrm{mg}, 24 \%)$.

(1R,3R,4aR,10aS,11S)-1-hydroxy-5,11-dimethyl-2a,3,4a,9,10,10a1-hexahydro-1H-2,4-dioxa-3,10amethanocyclohepta[bc]cyclopenta[jk]acenaphthylen-7(2a1H)-one (4).

${ }^{1} \mathrm{H}-\mathrm{NMR}\left(600 \mathrm{MHz}, \mathrm{CDCl}_{3}\right): \delta 6.98(\mathrm{~s}, 1 \mathrm{H}), 6.92(\mathrm{~s}, 1 \mathrm{H}), 5.33(\mathrm{~d}, J=5.3 \mathrm{~Hz}, 1 \mathrm{H}), 5.15(\mathrm{~s}, 1 \mathrm{H})$, $4.61(\mathrm{t}, J=5.7 \mathrm{~Hz}, 1 \mathrm{H}), 3.72(\mathrm{~d}, J=5.7 \mathrm{~Hz}, 1 \mathrm{H}), 3.69(\mathrm{~d}, J=8.7 \mathrm{~Hz}, 1 \mathrm{H})$, $3.08(\mathrm{dt}, J=8.8,5.5 \mathrm{~Hz}, 1 \mathrm{H}), 2.91-2.83(\mathrm{~m}, 1 \mathrm{H}), 2.57(\mathrm{dd}, J=14.9,5.9 \mathrm{~Hz}, 1 \mathrm{H}), 2.38(\mathrm{~s}$, $3 \mathrm{H}), 2.05(\mathrm{dd}, J=13.9,8.1 \mathrm{~Hz}, 1 \mathrm{H}), 1.40(\mathrm{q}, J=7.7 \mathrm{~Hz}, 1 \mathrm{H}), 1.30(\mathrm{td}, J=13.1,5.9 \mathrm{~Hz}, 2 \mathrm{H})$, $0.91(\mathrm{~d}, J=7.6 \mathrm{~Hz}, 3 \mathrm{H}) .{ }^{13} \mathrm{C}-\mathrm{NMR}\left(151 \mathrm{MHz}, \mathrm{CDCl}_{3}\right): \delta 186.78,149.61,146.69,146.50,144.64$, 140.76, 138.95, 91.82, 87.42, 80.99, 74.86, 42.68, 41.05, 39.54, 38.67, 33.14, 24.79, 24.30, 13.72. HR-MS(ESI) $m / z$ : 335.1252, [M + Na] ${ }^{+}$(Calcd for $\left.\mathrm{C}_{19} \mathrm{H}_{20} \mathrm{NNaO}_{4}: 335.1254\right)$.

To a solution of $4(10 \mathrm{mg}, 0.032 \mathrm{mmol})$ in dry pyridine $(0.5 \mathrm{~mL}, 6.2 \mathrm{mmol})$ at $0{ }^{\circ} \mathrm{C}$, acetic anhydride $(0.5 \mathrm{~mL}, 5.3 \mathrm{mmol})$ was added slowly. The reaction mixture was then allowed to warm to room temperature and stirred for $2 \mathrm{~h}$. The mixture was slowly poured into $15 \mathrm{~mL}$ of fast-stirring ice water. The solution was extracted with $\mathrm{CH}_{2} \mathrm{Cl}_{2}$ and washed with $1 \mathrm{M}$ $\mathrm{HCl}$, water, and brine. After the solution was dried over $\mathrm{Na}_{2} \mathrm{SO}_{4}$ and filtered, the solvent was removed to give a crude product. The residue was purified by column chromatography on silica gel by eluting with hexanes-EtOAc (1:1) to furnish the corresponding 5 as a yellow solid (10.4 mg, 92\%). 
(1S,3R,4aR,10aS,11S)-5,11-dimethyl-7-oxo-2a,2a1,3,4a,7,9,10,10a1-octahydro-1H-2,4-dioxa-3,10amethanocyclohepta[bc]cyclopenta[jk]acenaphthylen-1-yl acetate (5).

${ }^{1} \mathrm{H}-\mathrm{NMR} \quad\left(500 \mathrm{MHz}, \mathrm{CDCl}_{3}\right): \quad \delta 6.95 \quad(\mathrm{~s}, 1 \mathrm{H}), 6.87 \quad(\mathrm{~s}, 1 \mathrm{H}), 6.01 \quad(\mathrm{~s}, \quad 1 \mathrm{H})$, $5.33(\mathrm{~d}, J=5.4 \mathrm{~Hz}, 1 \mathrm{H}), 4.66(\mathrm{t}, J=5.7 \mathrm{~Hz}, 1 \mathrm{H}), 3.75(\mathrm{~d}, J=5.6 \mathrm{~Hz}, 1 \mathrm{H})$, $3.61(\mathrm{~d}, J=8.8 \mathrm{~Hz}, 1 \mathrm{H}), 3.10(\mathrm{dt}, J=8.7,5.5 \mathrm{~Hz}, 1 \mathrm{H}), 2.82(\mathrm{dddd}, J=14.6,12.3,8.1,2.0 \mathrm{~Hz}, 1 \mathrm{H})$, $2.56(\mathrm{dd}, J=15.0,6.0 \mathrm{~Hz}, 1 \mathrm{H}), 2.36(\mathrm{~s}, 3 \mathrm{H}), 2.18(\mathrm{~s}, 3 \mathrm{H}), 1.83(\mathrm{dd}, J=14.2,8.0 \mathrm{~Hz}, 1 \mathrm{H}), 1.49$ $(\mathrm{q}, J=7.6 \mathrm{~Hz}, 1 \mathrm{H}), 1.37(\mathrm{ddd}, J=14.2,12.4,6.1 \mathrm{~Hz}, 1 \mathrm{H}), 0.97(\mathrm{~d}, J=7.6 \mathrm{~Hz}, 3 \mathrm{H}) .{ }^{13} \mathrm{C}-\mathrm{NMR}$ $\left(126 \mathrm{MHz} \mathrm{CDCl}_{3}\right): \delta 186.76,170.79,148.24,146.30,145.77,144.28,141.03,139.15,91.92$, $87.46,80.72,75.18,43.77,41.07,38.54,38.28,32.90,24.38,24.20,21.61,13.67$. HR-MS(ESI) $m / z: 377.1354,[\mathrm{M}+\mathrm{Na}]^{+}\left(\right.$Calcd for $\left.\mathrm{C}_{21} \mathrm{H}_{22} \mathrm{NaO}_{5}: 377.1359\right)$.

\subsubsection{General Procedure for the Synthesis of Compounds 6 and 7}

A round-bottom flask was charged with selenium dioxide $\left(\mathrm{SeO}_{2}, 14.2 \mathrm{mg}, 0.128 \mathrm{mmol}\right)$ and tert-butyl hydroperoxide (TBHP, $5.5 \mathrm{M}$ solution in hexane, $145.5 \mu \mathrm{L}, 0.8 \mathrm{mmol}$ ). The resulting mixture was diluted with dichloromethane $(4.0 \mathrm{~mL})$ and stirred at $\mathrm{rt}$ for $30 \mathrm{~min}$. Then, the solution was added to compound $\mathbf{1}(100 \mathrm{mg}, 0.32 \mathrm{mmol})$ in $\mathrm{CH}_{2} \mathrm{Cl}_{2}(2 \mathrm{~mL})$ and stirred for the next $24 \mathrm{~h}$. The reaction was quenched with saturated aqueous $\mathrm{Na}_{2} \mathrm{SO}_{3}$ solution and extracted with $\mathrm{CH}_{2} \mathrm{Cl}_{2}$. The combined organic layers were washed with brine and dried $\left(\mathrm{Na}_{2} \mathrm{SO}_{4}\right)$, the solvent was removed to give a crude product. The obtained crude product was purified by column chromatography hexanes-EtOAc (3:2) to afford 6 (15.8 mg, $16 \%)$ and $7(4.7 \mathrm{mg}, 5 \%)$ as a yellow solid.

(3R,4aR,10aS,11S)-5,11-dimethyl-2a,3,4a,10a1-tetrahydro-1H-2,4-dioxa-3,10a

methanocyclohepta[bc]cyclopentaljk]acenaphthylene-1,7(2a1H)-dione (6).

${ }^{1} \mathrm{H}-\mathrm{NMR}\left(600 \mathrm{MHz}, \mathrm{CDCl}_{3}\right): \delta 6.80(\mathrm{~s}, 1 \mathrm{H}), 6.69(\mathrm{~d}, J=9.5 \mathrm{~Hz}, 1 \mathrm{H}), 6.61(\mathrm{~d}, J=2.5 \mathrm{~Hz}, 1 \mathrm{H})$, $6.42(\mathrm{~d}, J=9.6 \mathrm{~Hz}, 1 \mathrm{H}), 5.34(\mathrm{~d}, J=5.1 \mathrm{~Hz}, 1 \mathrm{H}), 5.23(\mathrm{t}, J=5.7 \mathrm{~Hz}, 1 \mathrm{H}), 4.03(\mathrm{~d}, J=5.6 \mathrm{~Hz}$, $1 \mathrm{H}), 3.61(\mathrm{~d}, J=8.9 \mathrm{~Hz}, 1 \mathrm{H}), 3.34(\mathrm{dt}, J=9.0,5.4 \mathrm{~Hz}, 1 \mathrm{H}), 2.32(\mathrm{~s}, 3 \mathrm{H}), 2.20(\mathrm{q}, J=7.6 \mathrm{~Hz}$, $1 \mathrm{H}), 0.95(\mathrm{~d}, J=7.6 \mathrm{~Hz}, 3 \mathrm{H}) .{ }^{13} \mathrm{C}-\mathrm{NMR}\left(151 \mathrm{MHz}, \mathrm{CDCl}_{3}\right): \delta 187.69,171.24,144.65,143.89$, $142.98,140.33,139.29,136.17,134.28,131.23,86.53,80.58,80.35,52.28,47.99,41.56,39.99$, 23.48, 15.95. HR-MS(ESI) $m / z:$ 331.0941, $[\mathrm{M}+\mathrm{Na}]^{+}$(Calcd for $\mathrm{C}_{19} \mathrm{H}_{16} \mathrm{NaO}_{4}$ : 331.0941).

(3R,4aR,9aS,10S)-5,10-dimethyl-2a,2a1,4a,9a1-tetrahydro-1H,3H-2,4-dioxa-3,9a-

methanopentaleno [4,3,2,1-cdef]phenanthrene-1,8(9H)-dione (7).

${ }^{1} \mathrm{H}-\mathrm{NMR}\left(600 \mathrm{MHz}, \mathrm{CDCl}_{3}\right): \delta 7.65(\mathrm{~d}, J=7.7 \mathrm{~Hz}, 1 \mathrm{H}), 7.28(\mathrm{~s}, 1 \mathrm{H}), 5.60(\mathrm{~d}, J=4.1 \mathrm{~Hz}$, $1 \mathrm{H}), 5.25(\mathrm{t}, J=5.3 \mathrm{~Hz}, 1 \mathrm{H}), 3.88(\mathrm{~d}, J=5.6 \mathrm{~Hz}, 1 \mathrm{H}), 3.65-3.58(\mathrm{~m}, 2 \mathrm{H}), 3.08(\mathrm{~d}, J=19.3 \mathrm{~Hz}$, $1 \mathrm{H}), 2.68(\mathrm{~d}, J=19.3 \mathrm{~Hz}, 1 \mathrm{H}), 2.48(\mathrm{~s}, 3 \mathrm{H}), 1.21(\mathrm{q}, J=7.6 \mathrm{~Hz}, 1 \mathrm{H}), 0.83(\mathrm{~d}, J=7.6 \mathrm{~Hz}, 3 \mathrm{H})$. ${ }^{13} \mathrm{C}-\mathrm{NMR}\left(151 \mathrm{MHz}, \mathrm{CDCl}_{3}\right): \delta 194.75,172.67,147.35,143.87,141.41,131.60,129.08,127.23$, 82.94, 80.08, 78.94, 47.56, 47.13, 42.81, 40.14, 37.99, 18.91, 15.29. HR-MS(ESI) m/z: 319.0939, $[\mathrm{M}+\mathrm{Na}]^{+}\left(\right.$Calcd for $\left.\mathrm{C}_{18} \mathrm{H}_{16} \mathrm{NaO}_{4}: 319.0941\right)$.

\subsubsection{General Procedure for the Synthesis of Compounds 8-13}

To a stirred solution of $\mathbf{1}(620 \mathrm{mg}, 2 \mathrm{mmol})$ in 1,2-dichloroethane (100 mL), NBromosuccinimide (NBS; $427.2 \mathrm{mg}, 2.4 \mathrm{mmol}$ ), in 3 portions every $6 \mathrm{~h}$, and azodiisobutyronitrile (AIBN; $10.7 \mathrm{mg}, 0.065 \mathrm{mmol}$ ) were added. The reaction mixture was heated at $80{ }^{\circ} \mathrm{C}$ for $18 \mathrm{~h}$. After cooling, the reaction solution was evaporated in vacuo and diluted with $\mathrm{CH}_{2} \mathrm{Cl}_{2}$, washed with $\mathrm{H}_{2} \mathrm{O}$ and brine, dried, and concentrated. The residue was purified by column chromatography on silica gel $\mathrm{CH}_{2} \mathrm{Cl}_{2}$-EtOAc (20:1) to give 8 as a yellow solid (419 $\mathrm{mg}, 54 \%)$.

(3R,4aR,9R,10aS,11S)-9-bromo-5,11-dimethyl-2a,3,4a,9,10,10a1-hexahydro-1H-2,4-dioxa3,10a-methanocyclohepta[bc]cyclopenta[jk]acenaphthylene-1,7(2a1H)-dione (8).

${ }^{1} \mathrm{H}-\mathrm{NMR}\left(500 \mathrm{MHz}, \mathrm{CDCl}_{3}\right): \delta 6.97(\mathrm{~s}, 1 \mathrm{H}), 6.94(\mathrm{~d}, J=2.5 \mathrm{~Hz}, 1 \mathrm{H})$, $5.37(\mathrm{~d}, J=5.3 \mathrm{~Hz}, 1 \mathrm{H}), 5.23(\mathrm{t}, J=5.7 \mathrm{~Hz}, 1 \mathrm{H}), 5.16(\mathrm{~d}, J=6.2 \mathrm{~Hz}, 1 \mathrm{H}), 4.46(\mathrm{~d}, J=9.0 \mathrm{~Hz}, 1 \mathrm{H})$, $4.01(\mathrm{~d}, J=5.6 \mathrm{~Hz}, 1 \mathrm{H}), 3.47(\mathrm{dt}, J=8.9,5.6 \mathrm{~Hz}, 1 \mathrm{H}), 3.34(\mathrm{~d}, J=17.0 \mathrm{~Hz}, 1 \mathrm{H}), 2.38(\mathrm{~s}, 3 \mathrm{H})$, $2.11(\mathrm{dd}, J=17.0,6.2 \mathrm{~Hz}, 1 \mathrm{H}), 1.79$ (q, $J=7.6 \mathrm{~Hz}, 1 \mathrm{H}), 0.87(\mathrm{~d}, J=7.5 \mathrm{~Hz}, 3 \mathrm{H}) .{ }^{13} \mathrm{C}-\mathrm{NMR}$ $\left(126 \mathrm{MHz} \mathrm{CDCl}_{3}\right): \delta 186.28,172.59,147.43,144.36,144.19,143.14,141.90,139.12,85.81$, 
80.00, 79.78, 47.82, 47.23, 45.84, 41.67, 40.04, 32.78, 24.22, 14.88. HR-MS(ESI) m/z: 411.0199, $[\mathrm{M}+\mathrm{Na}]^{+}$(Calcd for $\mathrm{C}_{19} \mathrm{H}_{17} \mathrm{BrNaO}_{4}: 411.0202$ ).

To a solution of $8(10 \mathrm{mg}, 0.026 \mathrm{mmol})$ in $\mathrm{MeOH}(0.5 \mathrm{~mL})$ at $0{ }^{\circ} \mathrm{C}, \mathrm{MeONa}(3.5 \mathrm{mg}$, $0.064 \mathrm{mmol}$ ) was added slowly. The reaction mixture was then allowed to warm to room temperature and stirred for $3 \mathrm{~h}$. The mixture was slowly poured into $10 \mathrm{~mL}$ water to quench the reaction. The solution was extracted with $\mathrm{CH}_{2} \mathrm{Cl}_{2}$ and washed with water, and brine. After the solution was dried over $\mathrm{Na}_{2} \mathrm{SO}_{4}$ and filtered, the solvent was removed to give a crude product. The residue was purified by column chromatography on silica gel by eluting with hexanes-EtOAc (3:2) to furnish the corresponding 9 as a white solid (7.8 $\mathrm{mg}, 88 \%)$.

(3R,4aR,10aS,11S)-8-methoxy-5,11-dimethyl-2a,3,4a,9,10,10a1-hexahydro-1H-2,4-dioxa-3,10amethanocyclohepta[bc]cyclopenta[jk]acenaphthylene-1,7(2a1H)-dione (9).

${ }^{1} \mathrm{H}-\mathrm{NMR}\left(600 \mathrm{MHz}_{\mathrm{CDCl}}\right): \delta 7.04(\mathrm{~s}, 1 \mathrm{H}), 5.36(\mathrm{~d}, J=5.2 \mathrm{~Hz}, 1 \mathrm{H}), 5.19(\mathrm{t}, J=5.6 \mathrm{~Hz}$, $1 \mathrm{H}), 3.97(\mathrm{~d}, J=5.6 \mathrm{~Hz}, 1 \mathrm{H}), 3.92(\mathrm{~s}, 3 \mathrm{H}), 3.45(\mathrm{ddd}, J=15.9,6.4,1.3,1 \mathrm{H}), 3.40-3.33(\mathrm{~m}$, 2H), $2.84(\mathrm{ddd}, J=14.6,8.1,1.3,1 \mathrm{H}), 2.46(\mathrm{ddd}, J=15.9,12.3,8.1 \mathrm{~Hz}, 1 \mathrm{H}), 2.37(\mathrm{~s}, 3 \mathrm{H})$, $1.74(\mathrm{q}, J=7.6 \mathrm{~Hz}, 1 \mathrm{H}), 1.21(\mathrm{ddd}, J=14.7,12.4,6.4 \mathrm{~Hz}, 1 \mathrm{H}), 0.88(\mathrm{~d}, J=7.6 \mathrm{~Hz}, 3 \mathrm{H})$. ${ }^{13} \mathrm{C}-\mathrm{NMR}\left(151 \mathrm{MHz}, \mathrm{CDCl}_{3}\right): \delta 180.89,173.87,162.43,145.58,143.26,141.63,138.65,132.38$, $85.83,80.03,79.51,59.19,50.30,46.04,41.91,40.59,24.51,23.34,22.32,14.83$. HR-MS(ESI) $m / z: 363.1202,[\mathrm{M}+\mathrm{Na}]^{+}$(Calcd for $\left.\mathrm{C}_{20} \mathrm{H}_{20} \mathrm{NaO}_{5}: 363.1203\right)$.

Compound 8 (388 mg, $1 \mathrm{mmol}$ ) was dissolved in a solution of acetone and water $(1: 1,5 \mathrm{~mL})$ and then $\mathrm{AgBF}_{4}(973.5 \mathrm{mg}, 5 \mathrm{mmol})$ was added. After stirring for $2 \mathrm{~h}$ at $70{ }^{\circ} \mathrm{C}$, the reaction mixture was diluted with $\mathrm{CH}_{2} \mathrm{Cl}_{2}$ and washed with water. The layers were separated and the aqueous layer was extracted with $\mathrm{CH}_{2} \mathrm{Cl}_{2}$. The combined organic layers were dried over $\mathrm{Na}_{2} \mathrm{SO}_{4}$, filtered, and concentrated under reduced pressure. The crude residue was purified by column chromatography hexanes-EtOAc (1:2) to afford 10 (153.2 $\mathrm{mg}, 47 \%$ yield) and 12 as yellow solids (68.5 $\mathrm{mg}, 21 \%$ yield).

(3R,4aR,9S,10aS,11S)-9-hydroxy-5,11-dimethyl-2a,3,4a,9,10,10a1-hexahydro-1H-2,4-dioxa-3,10amethanocyclohepta[bc]cyclopentaljk]acenaphthylene-1,7(2a1H)-dione (10).

${ }^{1} \mathrm{H}-\mathrm{NMR}\left(600 \mathrm{MHz}, \mathrm{CDCl}_{3}\right): \delta 7.41(\mathrm{~s}, 1 \mathrm{H}), 7.00(\mathrm{~s}, 1 \mathrm{H}), 5.35(\mathrm{~d}, J=5.4 \mathrm{~Hz}, 1 \mathrm{H})$, $5.18(\mathrm{t}, J=5.7 \mathrm{~Hz}, 1 \mathrm{H}), 4.87(\mathrm{t}, J=9.1 \mathrm{~Hz}, 1 \mathrm{H}), 3.97(\mathrm{~d}, J=5.6 \mathrm{~Hz}, 1 \mathrm{H})$, $3.45(\mathrm{~d}, J=8.9 \mathrm{~Hz}, 1 \mathrm{H}), 3.36(\mathrm{dt}, J=8.8,5.7 \mathrm{~Hz}, 1 \mathrm{H}), 3.21(\mathrm{dd}, J=14.2,7.9 \mathrm{~Hz}, 1 \mathrm{H})$, $2.38(\mathrm{~s}, 3 \mathrm{H}), 1.73(\mathrm{q}, J=7.6 \mathrm{~Hz}, 1 \mathrm{H}), 1.18(\mathrm{dd}, J=14.2,10.7 \mathrm{~Hz}, 1 \mathrm{H}), 0.88(\mathrm{~d}, J=7.6 \mathrm{~Hz}$, 3H). ${ }^{13} \mathrm{C}-\mathrm{NMR}\left(151 \mathrm{MHz}, \mathrm{CDCl}_{3}\right): \delta 187.20,173.10,148.51,146.34,144.66,143.94,141.81$, $135.35,85.79,80.10,79.51,68.25,48.44,44.91,42.12,40.09,31.96,24.19,14.86$. HR-MS(ESI) $m / z: 327.1229,[\mathrm{M}+\mathrm{H}]^{+}$(Calcd for $\left.\mathrm{C}_{19} \mathrm{H}_{19} \mathrm{O}_{5}: 327.1227\right)$.

(3R,4aR,9R,10aS,11S)-9-hydroxy-5,11-dimethyl-2a,3,4a,9,10,10a1-hexahydro-1H-2,4-dioxa-3,10amethanocyclohepta[bc]cyclopenta[jk]acenaphthylene-1,7(2a1H)-dione (12).

${ }^{1} \mathrm{H}-\mathrm{NMR}(600 \mathrm{MHz}, \mathrm{MeOD}): \delta 6.82(\mathrm{~s}, 1 \mathrm{H}), 6.75(\mathrm{~d}, J=2.5 \mathrm{~Hz}, 1 \mathrm{H}), 5.78(\mathrm{~d}, J=2.6 \mathrm{~Hz}, 1 \mathrm{H})$, $5.34(\mathrm{~d}, J=5.4 \mathrm{~Hz}, 1 \mathrm{H}), 5.21(\mathrm{t}, J=5.7 \mathrm{~Hz}, 1 \mathrm{H}), 4.61-4.59(\mathrm{~m}, 1 \mathrm{H}), 4.05(\mathrm{~d}, J=9.0 \mathrm{~Hz}, 1 \mathrm{H})$, $3.92(\mathrm{~d}, J=5.6 \mathrm{~Hz}, 1 \mathrm{H}), 3.40(\mathrm{dt}, J=9.1,5.6 \mathrm{~Hz}, 1 \mathrm{H}), 2.52(\mathrm{dd}, J=15.4,1.2 \mathrm{~Hz}, 1 \mathrm{H}), 2.29$ (s, 3H), 1.56-1.46 (m, 2H), 0.70 (d, $J=7.5 \mathrm{~Hz}, 3 \mathrm{H}) .{ }^{13} \mathrm{C}-\mathrm{NMR}$ (151 MHz, MeOD): $\delta$ 195.28, 182.96, 156.04, 155.08, 154.31, 154.02, 149.58, 148.23, 94.68, 89.02, 88.07, 81.60, 56.58, 54.84, $50.35,48.56,40.35,32.95,24.25$. HR-MS(ESI) $m / z: 327.1228,[\mathrm{M}+\mathrm{H}]^{+}\left(\right.$Calcd for $\mathrm{C}_{19} \mathrm{H}_{19} \mathrm{O}_{5}$ : 327.1227).

To a solution of compound $10(10 \mathrm{mg}, 0.03 \mathrm{mmol})$ in $2 \mathrm{~mL}$ of anhydrous dichloromethane, 1-(3-(dimethylamino)propyl)-3-ethylcarbodiimide hydrochloride (EDCI; $11.5 \mathrm{mg}, 0.06 \mathrm{mmol}$ ), DMAP (catalytic amount), and carboxylic acid $(0.045 \mathrm{mmol})$ were added. The resulting solution was stirred at room temperature for $4 \mathrm{~h}$. Then, the reaction was quenched with water and extracted with EtOAc. The combined organic phases were washed with brine, dried over $\mathrm{Na}_{2} \mathrm{SO}_{4}$, and concentrated in vacuo. The residue was subjected to column chromatography hexanes-EtOAc (1:1) to afford 11a-11f as white solids.

(3R,4aR,9S,10aS,11S)-5,11-dimethyl-1,7-dioxo-2a,2a1,3,4a,7,9,10,10a1-octahydro-1H-2,4-dioxa-3,10amethanocyclohepta[bc]cyclopenta[jk]acenaphthylen-9-yl acetate (11a). Yield: 96\% (10.6 mg). 
${ }^{1} \mathrm{H}-\mathrm{NMR}\left(500 \mathrm{MHz}, \mathrm{CDCl}_{3}\right): \delta 6.99(\mathrm{~s}, 1 \mathrm{H}), 6.94(\mathrm{t}, J=2.3 \mathrm{~Hz}, 1 \mathrm{H}), 5.93(\mathrm{ddd}, J=10.4,8.0$, $2.0 \mathrm{~Hz}, 1 \mathrm{H}), 5.36(\mathrm{~d}, J=5.4 \mathrm{~Hz}, 1 \mathrm{H}), 5.19(\mathrm{t}, J=5.7 \mathrm{~Hz}, 1 \mathrm{H}), 3.98(\mathrm{~d}, J=5.6 \mathrm{~Hz}, 1 \mathrm{H}), 3.52$ $(\mathrm{d}, J=8.8 \mathrm{~Hz}, 1 \mathrm{H}), 3.38(\mathrm{dt}, J=9.0,5.7 \mathrm{~Hz}, 1 \mathrm{H}), 3.20(\mathrm{dd}, J=8.8,5.7 \mathrm{~Hz}, 1 \mathrm{H}), 2.38(\mathrm{~s}, 3 \mathrm{H})$, $2.22(\mathrm{~s}, 3 \mathrm{H}), 1.79(\mathrm{q}, J=7.5 \mathrm{~Hz}, 1 \mathrm{H}), 1.23(\mathrm{dd}, J=14.0,10.7 \mathrm{~Hz}, 1 \mathrm{H}), 0.99(\mathrm{~d}, J=7.5 \mathrm{~Hz}$, 3H). ${ }^{13} \mathrm{C}-\mathrm{NMR}\left(126 \mathrm{MHz}, \mathrm{CDCl}_{3}\right): \delta 186.30,172.31,169.39,146.58,143.89,142.89,142.67$, $142.18,135.17,85.90,80.04,79.51,68.63,48.74,44.68,42.11,39.97,29.19,24.09,20.98,14.84$. HR-MS(ESI) $m / z: 391.1145,[\mathrm{M}+\mathrm{H}]^{+}$(Calcd for $\left.\mathrm{C}_{21} \mathrm{H}_{20} \mathrm{NaO}_{6}: 391.1152\right)$.

4-(((3R,4aR,9S,10aS,11S)-5,11-dimethyl-1,7-dioxo-2a,2a1,3,4a,7,9,10,10a1-octahydro-1H-2,4-dioxa3,10a-methanocyclohepta[bc]cyclopenta[jk]acenaphthylen-9-yl)oxy)-4-oxobutanoic acid (11b). Yield: $86 \%$ (11.0 mg).

${ }^{1} \mathrm{H}-\mathrm{NMR}\left(500 \mathrm{MHz}, \mathrm{CDCl}_{3}\right): \delta 7.19(\mathrm{~d}, J=2.2 \mathrm{~Hz}, 1 \mathrm{H}), 7.01(\mathrm{~s}, 1 \mathrm{H}), 5.98(\mathrm{ddd}, J=10.3$, $8.1,1.9 \mathrm{~Hz}, 1 \mathrm{H}), 5.37(\mathrm{~d}, J=5.4 \mathrm{~Hz}, 1 \mathrm{H}), 5.20(\mathrm{t}, J=5.8 \mathrm{~Hz}, 1 \mathrm{H}), 3.98(\mathrm{~d}, J=5.6 \mathrm{~Hz}, 1 \mathrm{H})$, $3.55(\mathrm{~d}, J=8.8 \mathrm{~Hz}, 1 \mathrm{H}), 3.42(\mathrm{dt}, J=8.8,5.6 \mathrm{~Hz}, 1 \mathrm{H}), 3.18(\mathrm{dd}, J=14.0,8.1 \mathrm{~Hz}, 1 \mathrm{H})$, 2.91 (ddd, $J=16.5,9.8,3.2 \mathrm{~Hz}, 1 \mathrm{H}), 2.82-2.68(\mathrm{~m}, 3 \mathrm{H}), 2.39(\mathrm{~s}, 3 \mathrm{H}), 1.74(\mathrm{q}, J=7.6 \mathrm{~Hz}$, $1 \mathrm{H}), 0.88(\mathrm{~d}, J=7.5 \mathrm{~Hz}, 3 \mathrm{H}) .{ }^{13} \mathrm{C}-\mathrm{NMR}\left(126 \mathrm{MHz}, \mathrm{CDCl}_{3}\right): \delta 186.70,174.57,172.35,171.14$, $146.99,145.03,143.85,143.25,141.93,135.00,85.78,79.95,79.41,68.90,48.61,44.51,41.98$, 39.80, 29.21, 28.92, 28.81, 24.07, 14.69. HR-MS(ESI) $m / z: 449.1207$, $[\mathrm{M}+\mathrm{Na}]^{+}($Calcd for $\left.\mathrm{C}_{23} \mathrm{H}_{22} \mathrm{NaO}_{8}: 449.1207\right)$.

(3R,4aR,9S,10aS,11S)-5,11-dimethyl-1,7-dioxo-2a,2a1,3,4a,7,9,10,10a1-octahydro-1H-2,4-dioxa-3,10amethanocyclohepta[bc]cyclopentaljk]acenaphthylen-9-yl 4-morpholino-4-oxobutanoate (11c). Yield: $88 \%$ (11.1 mg).

${ }^{1} \mathrm{H}-\mathrm{NMR}\left(600 \mathrm{MHz}, \mathrm{CDCl}_{3}\right): \delta 7.65(\mathrm{dd}, J=1.7,0.8 \mathrm{~Hz}, 1 \mathrm{H}), 7.34(\mathrm{dd}, J=3.5,0.8 \mathrm{~Hz}$, $1 \mathrm{H}), 7.05(\mathrm{t}, J=2.2 \mathrm{~Hz}, 1 \mathrm{H}), 7.00(\mathrm{~s}, 1 \mathrm{H}), 6.58(\mathrm{dd}, J=3.5,1.7 \mathrm{~Hz}, 1 \mathrm{H}), 6.16(\mathrm{ddd}, J=10.4$, $8.1,2.0 \mathrm{~Hz}, 1 \mathrm{H}), 5.38(\mathrm{~d}, J=5.3 \mathrm{~Hz}, 1 \mathrm{H}), 5.21(\mathrm{t}, J=5.7 \mathrm{~Hz}, 1 \mathrm{H}), 4.00(\mathrm{~d}, J=5.6 \mathrm{~Hz}, 1 \mathrm{H})$, $3.58(\mathrm{~d}, J=8.7 \mathrm{~Hz}, 1 \mathrm{H}), 3.41(\mathrm{dt}, J=8.8,5.6 \mathrm{~Hz}, 1 \mathrm{H}), 3.31(\mathrm{dd}, J=14.0,8.1 \mathrm{~Hz}, 1 \mathrm{H}), 2.39$ $(\mathrm{s}, 3 \mathrm{H}), 1.84(\mathrm{q}, J=7.6 \mathrm{~Hz}, 1 \mathrm{H}), 1.39(\mathrm{dd}, J=14.1,10.9 \mathrm{~Hz}, 1 \mathrm{H}), 0.91(\mathrm{~d}, J=7.6 \mathrm{~Hz}, 3 \mathrm{H})$. ${ }^{13} \mathrm{C}-\mathrm{NMR}\left(151 \mathrm{MHz}, \mathrm{CDCl}_{3}\right): \delta 186.29,172.26,156.93,147.45,146.67,143.90,143.48,142.72$, $142.55,142.22$, 135.33, 119.83, 112.43, 85.90, 80.03, 79.49, 68.86, 48.77, 44.69, 42.12, 39.98, 29.24, 24.11, 14.87. HR-MS(ESI) $m / z: 443.1101$, [M + Na] ${ }^{+}\left(\right.$Calcd for $\mathrm{C}_{24} \mathrm{H}_{20} \mathrm{NaO}_{7}: 443.1101$ ). (3R,4aR,9S,10aS,11S)-5,11-dimethyl-1,7-dioxo-2a,2a1,3,4a,7,9,10,10a1-octahydro-1H-2,4-dioxa-3,10amethanocyclohepta[bc]cyclopentaljk]acenaphthylen-9-yl benzoate (11d). Yield: 82\% (10.6 mg).

${ }^{1} \mathrm{H}-\mathrm{NMR}\left(600 \mathrm{MHz}, \mathrm{CDCl}_{3}\right): \delta 8.12(\mathrm{~d}, J=7.8 \mathrm{~Hz}, 2 \mathrm{H}), 7.63(\mathrm{t}, J=7.4 \mathrm{~Hz}, 1 \mathrm{H})$, $7.49(\mathrm{t}, J=7.6 \mathrm{~Hz}, 2 \mathrm{H}), 7.05(\mathrm{~d}, J=2.0 \mathrm{~Hz}, 1 \mathrm{H}), 7.01(\mathrm{~s}, 1 \mathrm{H}), 6.20(\mathrm{ddd}, J=10.3,8.1$, $1.8 \mathrm{~Hz}, 1 \mathrm{H}), 5.39(\mathrm{~d}, J=5.3 \mathrm{~Hz}, 1 \mathrm{H}), 5.22(\mathrm{t}, J=5.7 \mathrm{~Hz}, 1 \mathrm{H}), 4.01(\mathrm{~d}, J=5.6 \mathrm{~Hz}, 1 \mathrm{H})$, $3.61(\mathrm{~d}, J=8.6 \mathrm{~Hz}, 1 \mathrm{H}), 3.42(\mathrm{dt}, J=9.0,5.7 \mathrm{~Hz}, 1 \mathrm{H}), 3.34(\mathrm{dd}, J=14.0,8.0 \mathrm{~Hz}, 1 \mathrm{H}), 2.39$ $(\mathrm{s}, 3 \mathrm{H}), 1.86(\mathrm{q}, J=7.5 \mathrm{~Hz}, 1 \mathrm{H}), 1.39(\mathrm{dd}, J=14.0,10.8 \mathrm{~Hz}, 1 \mathrm{H}), 0.92(\mathrm{~d}, J=7.5 \mathrm{~Hz}, 3 \mathrm{H})$. ${ }^{13} \mathrm{C}-\mathrm{NMR}\left(151 \mathrm{MHz}, \mathrm{CDCl}_{3}\right): \delta 186.31,172.34,164.98,146.66,143.90,143.13,142.72,142.22$, 135.31, 134.00, 130.09, 128.93, 128.81, 85.93, 80.06, 79.51, 69.08, 48.80, 44.71, 42.17, 40.00, 29.30, 24.12, 14.89. HR-MS(ESI) $m / z: 453.1308,[\mathrm{M}+\mathrm{Na}]^{+}$(Calcd for $\mathrm{C}_{26} \mathrm{H}_{22} \mathrm{NaO}_{6}: 453.1309$ ). (3R,4aR,9S,10aS,11S)-5,11-dimethyl-1,7-dioxo-2a,2a1,3,4a,7,9,10,10a1-octahydro-1H-2,4-dioxa-3,10amethanocyclohepta[bc]cyclopentaljk]acenaphthylen-9-yl picolinate (11e). Yield: $91 \%$ (11.8 mg).

${ }^{1} \mathrm{H}-\mathrm{NMR}\left(600 \mathrm{MHz}, \mathrm{CDCl}_{3}\right): \delta 8.82(\mathrm{~d}, J=4.3 \mathrm{~Hz}, 1 \mathrm{H}), 8.23(\mathrm{~d}, J=7.8 \mathrm{~Hz}, 1 \mathrm{H})$, $7.91(\mathrm{~d}, J=7.5 \mathrm{~Hz}, 1 \mathrm{H}), 7.56(\mathrm{dd}, J=7.7,4.6 \mathrm{~Hz}, 1 \mathrm{H}), 7.10(\mathrm{~d}, J=2.2 \mathrm{~Hz}, 1 \mathrm{H}), 6.99$ $(\mathrm{s}, 1 \mathrm{H}), 6.29(\mathrm{ddd}, J=10.6,8.2,1.9 \mathrm{~Hz}, 1 \mathrm{H}), 5.38(\mathrm{~d}, J=5.4 \mathrm{~Hz}, 1 \mathrm{H}), 5.22(\mathrm{t}, J=5.7 \mathrm{~Hz}$, $1 \mathrm{H}), 4.01(\mathrm{~d}, J=5.6 \mathrm{~Hz}, 1 \mathrm{H}), 3.61(\mathrm{~d}, J=8.8 \mathrm{~Hz}, 1 \mathrm{H}), 3.42(\mathrm{dt}, J=8.8,5.7 \mathrm{~Hz}, 1 \mathrm{H})$, $3.35(\mathrm{dd}, J=14.1,8.2 \mathrm{~Hz}, 1 \mathrm{H}), 2.39(\mathrm{~s}, 3 \mathrm{H}), 1.85(\mathrm{q}, J=7.6 \mathrm{~Hz}, 1 \mathrm{H}), 1.59(\mathrm{dd}, J=14.1$, $10.8 \mathrm{~Hz}, 1 \mathrm{H}), 0.91(\mathrm{~d}, J=7.6 \mathrm{~Hz}, 3 \mathrm{H}) .{ }^{13} \mathrm{C}-\mathrm{NMR}\left(151 \mathrm{MHz}, \mathrm{CDCl}_{3}\right): \delta 186.30,172.36,163.78$, $150.34,146.93,146.61,143.85,142.57,142.48,142.16,137.45,135.48,127.82,126.01,85.89$, 80.06, 79.52, 69.76, 48.85, 44.77, 42.05, 40.04, 28.95, 24.11, 14.86. HR-MS(ESI) $m / z: 454.1259$, $[\mathrm{M}+\mathrm{Na}]^{+}$(Calcd for $\left.\mathrm{C}_{25} \mathrm{H}_{21} \mathrm{NNaO}_{6}: 454.1261\right)$.

(3R,4aR,9S,10aS,11S)-5,11-dimethyl-1,7-dioxo-2a,2a1,3,4a,7,9,10,10a1-octahydro-1H-2,4-dioxa-3,10amethanocyclohepta[bc]cyclopenta[jk]acenaphthylen-9-yl 3,5,6-trimethylpyrazine-2-carboxylate (11f). Yield: $76 \%(10.8 \mathrm{mg})$. 
${ }^{1} \mathrm{H}-\mathrm{NMR}\left(600 \mathrm{MHz}, \mathrm{CDCl}_{3}\right): \delta 7.21(\mathrm{~d}, J=2.2 \mathrm{~Hz}, 1 \mathrm{H}), 6.99(\mathrm{~s}, 1 \mathrm{H}), 6.21(\mathrm{ddd}, J=10.5,8.1$, $2.0 \mathrm{~Hz}, 1 \mathrm{H}), 5.38(\mathrm{~d}, J=5.4 \mathrm{~Hz}, 1 \mathrm{H}), 5.22(\mathrm{t}, J=5.8 \mathrm{~Hz}, 1 \mathrm{H}), 4.01(\mathrm{~d}, J=5.6 \mathrm{~Hz}, 1 \mathrm{H}), 3.60$ $(\mathrm{d}, J=8.7 \mathrm{~Hz}, 1 \mathrm{H}), 3.42(\mathrm{dt}, J=8.7,5.7 \mathrm{~Hz}, 1 \mathrm{H}), 3.36(\mathrm{dd}, J=14.0,8.1 \mathrm{~Hz}, 1 \mathrm{H}), 2.79(\mathrm{~s}, 3 \mathrm{H})$, $2.60(\mathrm{~d}, J=3.3 \mathrm{~Hz}, 6 \mathrm{H}), 2.38(\mathrm{~s}, 3 \mathrm{H}), 1.86(\mathrm{q}, J=7.6 \mathrm{~Hz}, 1 \mathrm{H}), 1.50(\mathrm{dd}, J=14.0,10.8 \mathrm{~Hz}$, $1 \mathrm{H}), 0.91(\mathrm{~d}, J=7.6 \mathrm{~Hz}, 3 \mathrm{H}) .{ }^{13} \mathrm{C}-\mathrm{NMR}\left(151 \mathrm{MHz}, \mathrm{CDCl}_{3}\right): \delta 186.41,172.43,164.37,155.50$, $152.28,149.89,146.52,143.74,142.63,142.59,142.16,138.21,135.74,85.90,80.07,79.51,69.56$, 48.81, 44.82, 42.05, 40.04, 28.97, 24.07, 22.81, 22.41, 21.86, 14.90. HR-MS(ESI) m/z: 497.1679, $[\mathrm{M}+\mathrm{Na}]+\left(\right.$ Calcd for $\left.\mathrm{C}_{27} \mathrm{H}_{26} \mathrm{~N}_{2} \mathrm{NaO}_{6}: 497.1683\right)$.

To a stirred solution of $12(10 \mathrm{mg}, 0.03 \mathrm{mmol})$ in $\mathrm{CH}_{2} \mathrm{Cl}_{2}, \mathrm{DMP}(17 \mathrm{mg}, 0.04 \mathrm{mmol})$ was added. The reaction mixture was stirred at room temperature for $5 \mathrm{~h}$ and then diluted with $\mathrm{CH}_{2} \mathrm{Cl}_{2}$. The organic phase was dried $\left(\mathrm{Na}_{2} \mathrm{SO}_{4}\right)$ and filtered. Concentration of the filtrate gave a residue that was fractionated by column chromatography hexanes-EtOAc (1:1) to afford $13(7.6 \mathrm{mg}, 78 \%)$ as a yellow solid.

(3R,4aR,10aS,11S)-5,11-dimethyl-2a,3,4a,10a1-tetrahydro-1H-2,4-dioxa-3,10amethanocyclohepta[bc]cyclopentaljk]acenaphthylene-1,7,9(2a1H,10H)-trione (13).

${ }^{1} \mathrm{H}-\mathrm{NMR}\left(600 \mathrm{MHz}, \mathrm{CDCl}_{3}\right): \delta 7.45(\mathrm{~d}, J=2.7 \mathrm{~Hz}, 1 \mathrm{H}), 6.92(\mathrm{~s}, 1 \mathrm{H}), 5.39(\mathrm{~d}, J=5.1 \mathrm{~Hz}, 1 \mathrm{H})$, $5.27(\mathrm{t}, J=5.6 \mathrm{~Hz}, 1 \mathrm{H}), 4.07(\mathrm{~d}, J=5.6 \mathrm{~Hz}, 1 \mathrm{H}), 3.52(\mathrm{~d}, J=8.8 \mathrm{~Hz}, 1 \mathrm{H}), 3.45(\mathrm{dt}, J=8.8$, $5.3 \mathrm{~Hz}, 1 \mathrm{H}), 3.32(\mathrm{~d}, J=20.2 \mathrm{~Hz}, 1 \mathrm{H}), 2.71(\mathrm{~d}, J=20.2 \mathrm{~Hz}, 1 \mathrm{H}), 2.39(\mathrm{~s}, 3 \mathrm{H}), 2.13(\mathrm{q}, J=7.6 \mathrm{~Hz}$, $1 \mathrm{H}), 0.97(\mathrm{~d}, J=7.6 \mathrm{~Hz}, 3 \mathrm{H}) .{ }^{13} \mathrm{C}-\mathrm{NMR}\left(151 \mathrm{MHz}, \mathrm{CDCl}_{3}\right): \delta 195.24,187.10,171.84,147.25$, $144.85,142.44,141.23,139.49,136.09,85.31,79.80,79.44,50.49,45.15,40.28,38.90,38.71$, 23.90, 15.31. HR-MS(ESI) $m / z: 347.0886,[\mathrm{M}+\mathrm{H}]^{+}\left(\right.$Calcd for $\mathrm{C}_{19} \mathrm{H}_{16} \mathrm{NaO}_{5}$ : 347.0890$)$.

\subsection{Cell Culture}

HCT-116 (Human colon cancer cell line), A375 (human melanoma cancer cell line), A-549 (human lung adenocarcinoma cell line), Huh-7 (human hepatoma cancer cell line), and L-02 (normal hepatic cell line) were purchased from the Cell Bank of Shanghai Institute of Biochemistry and Cell Biology, Chinese Academy of Sciences (Shanghai, China). The cells were cultured in Dulbecco's modified Eagle medium (DMEM; NY, USA), which were all supplemented with $10 \%$ fetal bovine serum (FBS; NY, USA) at $37{ }^{\circ} \mathrm{C}$ with $5 \% \mathrm{CO}_{2}$.

\subsection{MTT Assay}

The cytotoxic activity was evaluated using the MTT assay. Briefly, cells were seeded in 96-well plates at a density of $5 \times 10^{3}$ cells/well in $100 \mu \mathrm{L}$ of DMEM medium at $37{ }^{\circ} \mathrm{C}$ for $24 \mathrm{~h}$. Stock solutions of test compounds were prepared in DMSO at concentration of $50 \mathrm{mM}$, and twofold serial dilution with a culture medium was performed to obtain appropriate concentrations right before the assay. After that, the cells were incubated with synthetic derivatives or cisplatin as a positive control at the various concentrations $(0.78125-50 \mu \mathrm{M})$ for $48 \mathrm{~h}$. Then, $20 \mu \mathrm{L}$ of 3-(4,5-Dimethylthiazol-2-yl)-2,5-diphenyltetrazolium bromide (MTT, Aladdin, Shanghai, China) solution ( $5 \mathrm{mg} / \mathrm{mL}$ in PBS) was added, and then the cells were incubated at $37^{\circ} \mathrm{C}$ for an additional $4 \mathrm{~h}$. The supernatant was removed, and $150 \mu \mathrm{L}$ of dimethyl sulfoxide was added to dissolve the MTT formazan. The optical density (OD) was measured on a microplate reader (SpectraMax Plus 384, Molecular Devices, Sunnyvale, CA, USA) at a wavelength of $570 \mathrm{~nm}$. The cytotoxic activity was expressed as the $\mathrm{IC}_{50}$ values. The above tests were repeated three times in parallel. Vehicle DMSO $(0.1 \%)$ was used as a negative control.

Supplementary Materials: The following are available online. Scheme S1: Possible mechanism for the formation of the derivatives 7; Scheme S2: Possible mechanism for the formation of the derivatives 9; Figure S1: NMR spectra for all compounds; Figure S2: Purity assay for all compounds [29-32].

Author Contributions: Conceptualization, L.K. and J.L.; methodology, X.W., L.G., C.C., Y.T., W.Z., L.K. and J.L.; investigation, X.W., Y.T., L.K. and J.L.; resources, L.K. and J.L.; writing-original draft preparation, X.W.; writing-review and editing, X.W., L.K. and J.L.; supervision, L.K. and J.L. All authors have read and agreed to the published version of the manuscript. 
Funding: This research was supported by the Drug Innovation Major Project (2018ZX09735002-003) and the Program for Chang Jiang Scholars and Innovative Research Team in University (IRT_15R63).

Institutional Review Board Statement: Not applicable.

Informed Consent Statement: Not applicable.

Data Availability Statement: The data presented in this study are available on request from the corresponding author.

Conflicts of Interest: The authors declare no conflict of interest.

Sample Availability: Samples of the compounds are not available from the authors.

\section{References}

1. He, Y.R.; Shen, Y.H.; Shan, L.; Yang, X.; Wen, B.; Ye, J.; Yuan, X.; Li, H.L.; Xu, X.K.; Zhang, W.D. Diterpenoid Lanceolatins A-G from Cephalotaxus Lanceolata and Their Anti-Inflammatory and Anti-Tumor Activities. RSC Adv. 2015, 5, 4126-4134. [CrossRef]

2. Huang, Q.; Guo, K.; Liu, Y.; Liu, Y.; Li, W.; Geng, H.; Wang, Y.; Li, S. Diterpenoids and Flavonoids from the Twigs of Cephalotaxus Fortunei Var. Alpina. Chem. Biodivers 2020, 17. [CrossRef] [PubMed]

3. Zhao, J.X.; Fan, Y.Y.; Xu, J.B.; Gan, L.S.; Xu, C.H.; Ding, J.; Yue, J.M. Diterpenoids and Lignans from Cephalotaxus Fortunei. J. Nat. Prod. 2017, 80, 356-362. [CrossRef]

4. Zhao, C.X.; Li, B.Q.; Shao, Z.X.; Li, D.H.; Jing, Y.K.; Li, Z.L.; Hua, H.M. Cephasinenoside A, a New Cephalotane Diterpenoid Glucoside from Cephalotaxus Sinensis. Tetrahedron Lett. 2019, 60, 151154. [CrossRef]

5. Li, Y.; Wang, Y.; Shao, Z.; Zhao, C.; Jing, Q.; Li, D.; Lin, B.; Jing, Y.; Li, Z.; Hua, H. Diterpenoids from Cephalotaxus Fortunei Var. Alpina and Their Cytotoxic Activity. Bioorg.c Chem. 2020, 103, 104226. [CrossRef]

6. Buta, J.G.; Flippen, J.L.; Lusby, W.R. Harringtonolide, a Plant Growth Inhibitory Tropone from Cephalotaxus Harringtonia (Forbes) K. Koch. J. Org. Chem. 1978, 43, 1002-1003. [CrossRef]

7. Kang, S.Q.; Cai, S.Y.; Teng, L. The Antiviral Effect of Hainanolide, A Compound Isolated from Cephaloyaxis Hainanensis. Acta Pharm Sin. 1981, 16, 867-868.

8. Ni, L.; Zhong, X.H.; Chen, X.J.; Zhang, B.J.; Bao, M.F.; Cai, X.H. Bioactive Norditerpenoids from Cephalotaxus Fortunei Var. Alpina and C. Lanceolata. Phytochemistry 2018, 151, 50-60. [CrossRef] [PubMed]

9. Evanno, L.; Jossang, A.; Pouplin, J.N.; Delaroche, D.; Herson, P.; Seuleiman, M.; Bodo, B.; Nay, B. Further Studies of the Norditerpene (+)-Harringtonolide Isolated from Cephalotaxus Harringtonia Var. Drupacea: Absolute Configuration, Cytotoxic and Antifungal Activities. Planta. Med. 2008, 74, 870-872. [CrossRef]

10. Zhang, H.J.; Hu, L.; Ma, Z.; Li, R.; Zhang, Z.; Tao, C.; Cheng, B.; Li, Y.; Wang, H.; Zhai, H. Total Synthesis of the Diterpenoid (+)-Harringtonolide. Angew. Chem. 2016, 128, 11810-11813. [CrossRef]

11. Ma, Z.; Cheng, B.; Zhai, H. Synthetic Studies Toward Harringtonolide. Asian J. Org. Chem. 2014, 3, 1097-1101. [CrossRef]

12. Abdelkafi, H.; Herson, P.; Nay, B. Asymmetric Synthesis of the Oxygenated Polycyclic System of (+)-Harringtonolide. Org. Lett. 2012, 14, 1270-1273. [CrossRef]

13. O'Sullivan, T.P.; Zhang, H.; Mander, L.N. Model Studies toward the Synthesis of the Bioactive Diterpenoid, Harringtonolide. Org. Biomol. Chem. 2007, 5, 2627. [CrossRef]

14. Frey, B.; Wells, A.P.; Rogers, D.H.; Mander, L.N. Synthesis of the Unusual Diterpenoid Tropones Hainanolidol and Harringtonolide. J. Am. Chem. Soc. 1998, 120, 1914-1915. [CrossRef]

15. Zhang, M.; Liu, N.; Tang, W. Stereoselective Total Synthesis of Hainanolidol and Harringtonolide via Oxidopyrylium-Based [5 + 2] Cycloaddition. J. Am. Chem. Soc. 2013, 135, 12434-12438. [CrossRef]

16. Zhang, H.B.; Appels, D.C.; Hockless, D.C.R.; Mander, L.N. A New Approach to the Total Synthesis of the Unusual Diterpenoid Tropone, Harringtonolide. Tetrahedron Lett. 1998, 39, 6577-6580. [CrossRef]

17. Abdelkafi, H.; Evanno, L.; Herson, P.; Nay, B. Synthetic Studies toward the Cytotoxic Norditerpene (+)-Harringtonolide: Setting up Key-Stereogenic Centers of the Cyclohexane Ring D. Tetrahedron Lett. 2011, 52, 3447-3450. [CrossRef]

18. Frey, B.; Mander, L.N.; Hockless, D.C.R. Ether Formation by Intramolecular Attack of Hydroxy on Cyclopropyl Rings: A Model for the Formation of the Tetrahydrofuran Moiety in the Diterpenoid, Harringtonolide. J. Chem. Soc. Perkin Trans. 1 1998, 1555-1560. [CrossRef]

19. Sun, N.J.; Xue, Z.; Liang, X.T.; Huang, L. Studies on the Structure of A New Antitumor Agent-Hainanolide. Acta Pharm. Sin. 1979, $14,41-46$.

20. Fan, Y.Y.; Xu, J.B.; Liu, H.C.; Gan, L.S.; Ding, J.; Yue, J.M. Cephanolides A-J, Cephalotane-Type Diterpenoids from Cephalotaxus Sinensis. J. Nat. Prod. 2017, 80, 3159-3166. [CrossRef]

21. Ge, Z.P.; Liu, H.C.; Wang, G.C.; Liu, Q.F.; Xu, C.F.; Xu, C.F.; Ding, J.; Fan, Y.Y.; Yue, J.M. 17-nor-Cephalotane-Type Diterpenoids from Cephalotaxus Fortunei. J. Nat. Prod. 2019, 82, 1565-1575. [CrossRef]

22. Du, J.; Chiu, M.H.; Nie, R.L. Two New Lactones from Cephalotaxus Fortunei Var. Alpnia. J. Nat. Prod. 1999, 62, 1664-1665. [CrossRef]

23. Ni, G.; Zhang, H.; Fan, Y.Y.; Liu, H.C.; Ding, J.; Yue, J.M. Mannolides A-C with an Intact Diterpenoid Skeleton Providing Insights on the Biosynthesis of Antitumor Cephalotaxus Troponoids. Org. Lett. 2016, 18, 1880-1883. [CrossRef] 
24. Wu, G.R.; Xu, B.; Yang, Y.Q.; Zhang, X.Y.; Fang, K.; Ma, T.; Wang, H.; Xue, N.N.; Chen, M.; Guo, W.B.; et al. Synthesis and Bio-logical Evaluation of Podophyllotoxin Derivatives as Selective Antitumor Agents. Eur. J. Med. Chem. 2018, 155, 183-196. [CrossRef] [PubMed]

25. Stern, P.H.; Hoffman, R.M. Enhanced In Vitro Selective Toxicity of Chemotherapeutic Agents for Human Cancer Cells Based on a Metabolic Defect. J. Natl. Cancer Inst. 1986, 76, 629-639. [CrossRef] [PubMed]

26. Haglund, C.; Åleskog, A.; Nygren, P.; Gullbo, J.; Höglund, M.; Wickström, M.; Larsson, R.; Lindhagen, E. In Vitro Evaluation of Clinical Activity and Toxicity of Anticancer Drugs Using Tumor Cells from Patients and Cells Representing Normal Tissues. Cancer Chemother. Pharmacol. 2012, 69, 697-707. [CrossRef]

27. You, Y.J.; Kim, Y.; Nam, N.H.; Ahn, B.Z. Synthesis and Cytotoxic Activity of A-Ring Modified Betulinic Acid Derivatives. Bioorg. Med. Chem. Lett. 2003, 13, 3137-3140. [CrossRef]

28. Rao, Z.; Liu, X.; Zhou, W.; Yi, J.; Li, S.S. Synthesis and Antitumour Activity of $\beta$-Hydroxyisovalerylshikonin Analogues. Eur. J. Med. Chem. 2011, 46, 3934-3941. [CrossRef]

29. Demidov, M.R.; Lapshina, M.Y.; Osipov, D.V.; Osyanin, V.A.; Klimochkin, Y.N. Oxidative Rearrangement of 4H-Chromenes to 2-Aroylbenzofurans in the Presence of Selenium Dioxide. Chem. Heterocycl. Comp. 2017, 53, 1053-1056. [CrossRef]

30. Morita, S.; Yoshimura, T.; Matsuo, J. Intramolecular Büchner Reaction and Oxidative Aromatization with SeO2 or O2. Chem. Pharm. Bull. 2019, 67, 729-732. [CrossRef]

31. Karimi, S.; Ma, S.; Ramig, K.; Greer, E.M.; Szalda, D.J.; Subramaniam, G. Oxidative Ring-Contraction of 3H-1-Benzazepines to Quinoline Derivatives. Tetrahedron Lett. 2015, 56, 6886-6889. [CrossRef]

32. Maier, W.F.; Roth, W.; Thies, I.; Schleyer, P.V.R. Hydrogenolysis, iv. gas phase decarboxylation of carboxylic acids. Chem. Ber. 1982, 115, 808-812. [CrossRef] 